\title{
ASIENTOS Y POLÍTICA NAVAL. EL SUMINISTRO DE VÍVERES A LA ARMADA AL INICIO DE LA GUERRA CONTRA GRAN BRETAÑA, 1739-1741
}

\section{Contractors and Naval Policy. The Victualling of the Spanish Navy in the Beginning of the War against Great Britain, 1739-1741}

María BAUDOT MONROY

UNED

Correo-e: mbaumon@gmail.com

RESUMEN: En 1739, al mismo tiempo que los representantes diplomáticos de Gran Bretaña y España negociaban para evitar una guerra, ambas naciones pusieron en marcha sus respectivas maquinarias de guerra. La movilización de recursos en España se vio muy condicionada por la quiebra financiera decretada en marzo de ese mismo año. Afrontar el avituallamiento de las escuadras fue un reto para Inglaterra, mientras que para España la necesidad de garantizar el aprovisionamiento condicionó las decisiones políticas y financieras y consolidó la posición de fuerza y los privilegios del asentista de víveres de la Armada a medida que aumentó la dependencia de la corona de sus servicios.

Palabras clave: Política naval, Armada siglo XVIII, provisión de víveres, asientos, financiación.

ABSTRACT: In 1739 while British and Spanish diplomats tried to avoid a war, both nations prepared the infrastructure to arm their respective Navies. The mobilization of the Spanish resources for war was very much hampered by the bankruptcy of March that same year. While for Britain the victualling of the fleet was a challenge, for Spain the need to ensure the 
supply of food conditioned the political and financial decisions and increased the contractors privileges as well as the dependency for their services of the crown.

Key words: Naval policy, Spanish Navy, Victualling, Contractors, Finances.

A lo largo de 1739, al mismo tiempo que los representantes diplomáticos de España y Gran Bretaña llevaban a cabo intensas negociaciones para evitar o, por lo menos, posponer una guerra que era inevitable, ambas naciones ponían en marcha sus respectivas maquinarias de guerra naval. Ese mismo año, en España se había decretado una suspensión de pagos. En el presente trabajo analizaremos las medidas tomadas por el Almirantazgo español y por la Secretaría de Marina, las dos instituciones que dirigieron (no siempre de común acuerdo) la política naval, para afrontar, en plena crisis financiera, uno de los mayores retos de aquel momento: el avituallamiento de las escuadras armadas en guerra en los departamentos marítimos peninsulares para defender las costas y plazas amenazadas de ser atacadas por buques ingleses. En un segundo plano estudiaremos, a través de la relación mantenida con el asentista de víveres, cómo la necesidad de garantizar el aprovisionamiento durante la guerra condicionó las decisiones políticas y financieras, así como la posición de fuerza y los privilegios que fue adquiriendo Miguel de Arizcun a medida que aumentaba la situación de dependencia de la corona.

Proveer de víveres puntual y eficazmente a una escuadra condicionaba decisivamente su capacidad estratégica. Un retraso en el aprovisionamiento demoraba irremediablemente el que pudiera hacerse a la vela en el tiempo previsto. Del mismo modo, la escasez o la falta de provisiones necesariamente obligaban a cortar una expedición o a levantar el bloqueo de un puerto, y, ya en un plano más dramático, si los alimentos estaban caducos porque habían estado mal envasados y almacenados, su pudrición podía diezmar rápidamente una tripulación, creando serios problemas en la gobernación de un buque de guerra a vela. De ahí que alimentar a esos miles de tripulantes embarcados durante varios meses, garantizando puntualmente la renovación de las provisiones y del agua, haya sido desde siempre el principal problema de las administraciones navales.

Mientras que Gran Bretaña abordaba este problema creando en 1684 una institución centralizada, el Victualling Board, dependiente del Navy Board, al que encomendó todas las actividades relacionadas con el aprovisionamiento de víveres (planificación, compra, almacenamiento, conservación, embalaje, distribución, transporte), en España, a pesar de que durante el ministerio de Patiño hubo algunos intentos de gestionar el avituallamiento mediante la administración directa por 
parte de la Secretaría de Marina, se siguió funcionando con el sistema de asientos privados con hombres de negocios. No obstante, la política de contratación con los asentistas evolucionó a lo largo del siglo hacia la creación de un monopolio y hacia la unidad de abastecimiento, es decir, hacia la promoción de un único asentista para todo el territorio nacional ${ }^{1}$.

El 21 de marzo de 1739, Juan Bautista de Iturralde, marqués de Murillo², a los pocos días de haber sido nombrado ministro de Hacienda, firmaba el «Decreto de suspensión de lo librado", anulando temporalmente todos los pagos pendientes de la Corona. Esta quiebra funcional del sistema financiero del Estado fue inevitable al estar adjudicadas a principios de 1739 todas las rentas de ese año y gran parte de las de 1740. La deuda acumulada ascendía a 490 millones de reales. Junto a la suspensión de pagos Iturralde también propuso a Felipe $\mathrm{V}$ medidas de ahorro adicionales $^{3}$ que suponían serias restricciones en los presupuestos de la Casa Real y en los de los secretarías de Guerra y Marina, las tres partidas de mayor gasto, lo cual, aunque pueda parecer comprensible desde el punto de vista del ministro de Hacienda, no deja de ser sorprendente, teniendo en cuenta que España y Gran Bretaña se encaminaban hacia una guerra que, en marzo de 1739, los gobernantes ya veían más que probable. La negativa del monarca a aceptar el grueso de los recortes en los ramos de Guerra y Marina, por tanto, parece justificada y explica la salida del Ministerio de Hacienda tanto de Iturralde, en enero de 1740, como en febrero de 1741 de su sucesor, Fernando Verdes Montenegro, que siguió la misma política de intentar equilibrar el gasto con los ingresos eliminando lo «superfluo». En consecuencia, cuando empieza la guerra y durante los dos primeros años, la Hacienda española está en una situación caótica, más centrada en las luchas

1. Un análisis de las distintas instituciones que gestionaron todo lo relacionado con la administración de la Royal Navy y de su funcionamiento en: Rodger, N. A. M.: The Wooden World. An Anatomy of the Georgian Navy. Norton \& Company, Nueva York, 1996, pp. 29-36.

Sobre la política española de asientos de víveres para la Armada en el siglo XVIII véase: TORRES SÁNCHEZ, R.: «Servir al rey, más una comisión. El fortalecimiento de los asentistas en la corona española durante la segunda mitad del siglo XVIII» en Fernández Albaladejo, P.: Monarquía, Imperio y pueblos en la España Moderna». Universidad de Alicante, AEHM, Alicante, 1997, pp.149-166. Del mismo autor: «Cuando las reglas del juego cambian. Mercados y privilegios en el abastecimiento del Ejército español en el siglo XVIII", Revista de Historia Moderna. Anales de la Universidad de Alicante, Varia, 20 (2002), pp. 5-66. «Los navarros en la provisión de víveres a la Armada española en el siglo XVIII» en TORRES SÁNCHEZ, (ed.): Volver a la hora navarra. La contribución navarra a la construcción de la Monarquia española en el siglo XVIII. Eunsa, Pamplona, 2010, pp. 213-262.

2. Iturralde pertenecía al reducido grupo de hombres de negocios y banqueros, en su mayoría navarros, que controlaban las finanzas públicas mediante asientos de rentas y créditos a la Hacienda. CRuz MundeT, J. R.: «Juan Bautista de Iturralde y Gamio, un asentista navarro en la corte de Felipe V», Principe de Viana, 255 (2012), pp. 205-259.

3. Archivo General de Simancas [en adelante AGS], Secretaría y Superintendencia de Hacienda [en adelante SSH], leg. 409. Hay una referencia a estos documentos en Perona Tomás, D.: Los orígenes del Ministerio de Marina. Ministerio de Defensa, Madrid, 1999, pp. 125-126 y 183. 
internas que suscitaron los intentos de reducir el gasto de las Casas Reales que en proponer soluciones viables para financiar la contienda ${ }^{4}$.

El 23 de octubre de ese mismo año Jorge II declaraba la guerra al rey de España. Se iniciaba así una contienda naval entre ambas naciones por el control del comercio colonial que, si en un principio se iba a desarrollar en aguas caribeñas, muy pronto adquirió carácter mundial al extenderse los enfrentamientos al Atlántico, al Pacífico, al Mediterráneo y, a partir de 1742, a suelo europeo, al encadenarse el conflicto con la Guerra de Sucesión austríaca. Las autoridades de ambas naciones habían puesto en marcha sus respectivas maquinarias de la guerra mucho antes de la declaración oficial. Lo cual no es de extrañar si tenemos en cuenta las dificultades y el tiempo que requería el proceso de armar una escuadra.

Desde principios de junio el Almirantazgo británico, aprovechando el entusiasmo popular hacia la guerra ${ }^{5}$, había ordenado empezar con la recluta de marinería voluntaria (el método habitual de reclutamiento), recurriendo además en esta ocasión a la recluta forzosa, al ordenar la retención en todos los puertos ingleses de cualquier embarcación lista para hacerse a la vela (incluidos los mercantes y pesqueros), hasta que la flota estuviera provista de los tripulantes necesarios ${ }^{6}$. Al no disponer del sistema de matrículas que existía en España ${ }^{7}$, conseguir suficientes marineros para formar las tripulaciones de las escuadras era el mayor problema al que tenía que hacer frente el Almirantazgo británico, viéndose obligado ante una movilización como la de 1739 a acudir a los reclutamientos forzosos, muy polémicos por los excesos cometidos por las patrullas de reclutamiento. En este sentido, no está de más recordar que la primera revuelta violenta de las colonias norteamericanas contra su metrópoli tuvo lugar en Boston en 1747, como consecuencia de la violencia empleada en las reclutas forzosas realizadas por el almirante Knowles para tripular las escuadras destacadas en Jamaica ${ }^{8}$.

4. Fernández Albaladejo, P.: «El decreto de suspensión de pagos de 1739: análisis e implicaciones», Moneda y Crédito, 142, 1977, pp. 51-85. JuRAdo SÁNCHEZ, J.: «Proyectos para reducir el gasto de la Hacienda española en el siglo XVIII», Cuadernos de Estudios Empresariales, 14 (2004), pp. 105-129. Delgado Barrado, Aquiles y Teseos...,

5. Sobre la campaña de prensa antiespañola para movilizar el apoyo popular y provocar que el Parlamento británico declarara la guerra a España, precipitando la caída de Walpole véase: WILSON, K.: The Sense of the People: Politics, Culture and Imperialism in England, 1715-1785. Cambridge University Press, Cambridge, 1998, pp. 140-205.

6. HaRding, R.: The Emergence of Britain's Global Naval Supremacy. The War of 1739-1748. The Boydell Press, Woodbridge, 2010, pp. 29 y 47-48.

7. Archivo General de la Marina «Don Álvaro de Bazán» [en adelante AGM], leg. 5159. San Ildefonso, 18 de octubre de 1737. Real Decreto para la creación de la Matrícula de Mar.

8. Sobre los sistemas de reclutamiento en Inglaterra: BAUGH, D.: British Naval Administration in the Age of Walpole. Princeton University Press, Princeton, 1965, pp. 147-240. RODGER, N. A. M.: The Wooden World..., pp. 145-204; sobre los excesos cometidos por las patrullas de reclutamiento y las consecuentes revueltas violentas en Gran Bretaña y en América véase BRUNSMAN, D.: 
Por el contrario, en el siglo xviII el avituallamiento ordinario había dejado de ser un problema para el Almirantazgo británico debido, en primer lugar, a que la política de mantener varias escuadras permanentemente armadas y tripuladas con un mínimo de 10.000 hombres en tiempo de paz había permitido dotar a la oficina encargada de la provisión de víveres de un sistema administrativo y financiero estable y bien constituido, que trabajaba sobre la base de estimaciones anuales bastante exactas de todos los alimentos que se iban a necesitar para confeccionar las raciones de armada para el año siguiente. Las previsiones se elaboraban con anticipación y se presentaban todos los septiembres, después de las cosechas de cereales y antes de las matanzas de animales que acababan en diciembre, teniendo así tiempo suficiente para preparar las conservas de carne y de tocino y para cocer el bizcocho. Esta organización sistematizada permitió que se consolidara un nutrido y variado grupo de proveedores dispuestos a depositar, en los almacenes que el servicio de avituallamiento tenía en los distintos arsenales y puertos, todo lo que se les pedía.

Un segundo factor rotundamente decisivo fue la capacidad de la Royal Navy para financiarse mediante la emisión de deuda pública en forma de bonos de Marina, bonos de avituallamiento, de hospitales etc., garantizados por el Estado mediante el visto bueno parlamentario de los tres presupuestos (gasto ordinario, servicio naval y gasto extraordinario) que tenía que presentar anualmente la dirección del Almirantazgo al Parlamento para su aprobación y, ocasionalmente, mediante la concesión de créditos extraordinarios. La forma de pago habitual de los funcionarios de la oficina de avituallamiento a los proveedores era mediante letras de cambio giradas contra la oficina de avituallamiento, el mismo sistema utilizado por los comandantes de los buques de guerra cuando navegaban por tierras lejanas y tenían que reponer los víveres y la aguada. La Tesorería de la Royal Navy aceptaba siempre estas letras de cambio y hacía frente puntualmente a los vencimientos de los bonos de deuda jugando con la partida presupuestaria ordinaria que correspondía a los sueldos de la marinería y de las maestranzas de los arsenales, de modo que todos los pagos a proveedores quedaban suficientemente garantizados, incluso cuando la demanda de víveres se disparaba y elevaba los precios, como ocurrió en 1739.

Para financiar esta guerra, el Parlamento aprobó el 14 de junio una emisión de deuda en bonos a largo plazo de 300.000 libras esterlinas, que el mercado absorbió

\footnotetext{
«The Knowles Atlantic Impressments Riots of the 1740s», Early American Studies, Fall (2007), pp. 324-366. Para España véase: Fernández Díaz, R. y Martínez Shaw, C.: «Las revistas de inspección de la Matrícula de Mar en el siglo XVIII» en MARTínez SHaw, C.: El Derecho y el mar en la España Moderna, Granada, 1995. VÁzQuez Lijó, J. M.: La matrícula de mar en la España del siglo XVIII. Ministerio de Defensa, Madrid, 2007, pp. 45-53.
} 
fácilmente 9 . Junto a los factores mencionados, durante este año en Inglaterra se dieron dos hechos puntuales que contribuyeron a que el aprovisionamiento no fuera un problema. Por un lado, la movilización de hasta 30.000 marineros empezó medio año antes de declararse la guerra y se hizo de forma gradual a lo largo de nueve meses, creciendo la demanda de víveres en consecuencia también de forma progresiva. Por otro lado, en los almacenes del servicio de avituallamiento todavía quedaban suministros suficientes de los aportados a lo largo de 1738 para atender el incremento de la demanda. Si tenemos en cuenta que Walpole, en su intento de detener la guerra, había pospuesto hasta marzo de 1739 la presentación de la previsión de raciones de armada para ese año, que debiera haber presentado en septiembre de 1738, no deja de ser sorprendente esta capacidad de respuesta del servicio de avituallamiento, que permitió la provisión de víveres para las distintas escuadras durante la movilización inicial sin muchos altibajos ni grandes dificultades ${ }^{10}$.

Veamos ahora qué ocurrió en España. Por lo pronto tenemos dos instituciones al frente de los asuntos de la Marina: la Secretaría del Despacho de Marina creada en 1714 que, tras unos titubeantes inicios en los que aparece unas veces unida a la de Guerra y otras a la de Indias, finalmente en 1721 se consolida como tal, y el Almirantazgo General de España e Indias (1737-1748), creado por Felipe V para «el aumento de las Fuerzas Marítimas que con tanto desvelo y aplicación he restablecido»y, sobre todo, para proporcionar al Infante Don Felipe de Borbón Parma una posición destacada y garantizarle unos jugosos ingresos. Teniendo en cuenta la juventud e inexperiencia del flamante Infante-Almirante General, para dotarle de la suficiente autoridad el rey le otorgó el mando supremo de la Armada ${ }^{11}$. Al Almirantazgo se le adjudicaron todas las competencias relacionadas con la jurisdicción y la gestión administrativa y operativa de la Armada (fuerzas navales, buques, armamentos, dotaciones, construcción naval, mantenimiento, avituallamiento etc.) y de la Marina en general (marina mercante, comercio, puertos, costas, industrias marítimas, montes, construcción naval, etc.). Para ejercer el gobierno de la nueva institución, se creó una Junta de Marina formada por tres expertos marinos, los tenientes generales marqués de Mari y Francisco Cornejo y el jefe de escuadra Rodrigo Torres, y un secretario, el comisario ordenador de Marina

9. HaRding, R.: The Emergence..., p. 53.

10. BAugh, D.: British Naval..., pp. 386-390 y 454-481.

11. Sobre la Secretaría del Despacho de Marina véase: Perona Tomás, D.: Los orígenes... Sobre el Almirantazgo: Pérez FernándeZ-Turégano, C.: «El Almirantazgo del Infante D. Felipe (17371748). Conflictos competenciales con la Secretaría de Estado y del Despacho de Marina», Anuario de Historia del Derecho español, 74 (2004), pp. 409-476. Ceballos-Escalera y Gila, A. de: El Almirantazgo general de España e Indias en la Edad Moderna, Real Academia de la Mar, Madrid, 2012. Perona Tomás, D.: Los orígenes..., pp. 115-124. 
Cenón de Somodevilla, futuro marqués de la Ensenada, a quien se encargó toda la gestión y la coordinación de la nueva institución, así como el mantenimiento de la correspondencia de oficio, firmada por él mismo en nombre del InfanteAlmirante, con el resto de la administración.

Con la adjudicación de tan amplias competencias al Almirantazgo, a la Secretaría de Marina le quedó la dirección política y económica, pero la realidad que refleja la documentación es que hasta noviembre de $1741^{12}$ ejerció de correa de transmisión entre el Almirantazgo, el secretario de Marina, el secretario de Estado, marqués de Villarias y el rey, con mayor o menor tensión, generada precisamente por la propia duplicidad en la gestión administrativa. Como ocurría cuando el secretario de Marina, dentro de sus competencias, comunicaba por la vía reservada alguna orden al Almirantazgo. Ensenada, argumentando que el Infante-Almirante tenía el mando supremo en la Armada, se quejaba oficialmente al rey, tratando de evitar que se le privara de información y de defender la independencia de la Institución. Otro tanto le ocurría al secretario de Marina, José de la Quintana, que veía con frecuencia su labor ensombrecida, al tener que presentar a la aprobación del monarca las propuestas que en nombre del Infante Almirante le hacía llegar constantemente el arrollador secretario de la Junta, un Ensenada que ya apuntaba maneras ${ }^{13}$. Es comprensible que una cadena de mando con tantos eslabones necesariamente ralentizara la toma de decisiones, como también que frecuentemente surgieran problemas de competencias entre las dos instituciones que se ocupaban de los asuntos de la Armada.

Una de las medidas propuestas por el nuevo secretario de Hacienda, Iturralde, en mayo de 1739, destinada a conseguir un equilibrio entre los gastos y las rentas disponibles de la Monarquía y a rebajar la enorme deuda acumulada, fue la de controlar y reducir todo lo «superfluo y vicioso» del presupuesto de la Armada. Para ello, a través del secretario de Marina, José de la Quintana, Iturralde ordenó a la Junta de Marina del Almirantazgo que le presentara presupuestos detallados

12. En noviembre de 1741 José del Campillo, que ya era secretario de Hacienda, Guerra, Marina e Indias, fue nombrado lugarteniente del Almirantazgo. Cuando unos meses más tarde el infante Don Felipe se fue a Italia acompañado de Ensenada, Campillo sucedió al Infante al frente del Almirantazgo, concentrando en su persona todos los cargos relacionados con la gestión de la Armada. Tras su muerte en abril de 1743 le sucedió en todos sus cargos el marqués de la Ensenada. PERONA TomÁs, D.: Los orígenes..., pp. 131-132.

13. Pérez Fernández-Turégano, C.: «El Almirantazgo...», capítulo V. Perona Tomás, D.: Los orígenes..., p. 129. Como secretario del Almirantazgo Ensenada puso en marcha muchas reformas para la Armada que completó siendo ya ministro, a partir de 1743. Una recopilación de las reformas emprendidas por el Almirantazgo entre 1737 y 1748 en Ceballos-Escalera y Gila, A. de: El Almirantazgo..., pp. 89-109 (cito por la tesis, UNED, 2005). La obra más completa sobre Ensenada y su proyecto global de reforma sigue siendo la de GÓMEZ URDÁNEZ, J. L.: El proyecto reformista de Ensenada. Milenio, Lérida, 1996. 
de todos los gastos para su fiscalización por la Junta de Hacienda y posterior aprobación por Felipe $\mathrm{V}^{14}$. Esta medida implicaba una considerable reducción de las consignaciones y la intervención del secretario de Hacienda en las cuentas de la Armada, cuyo lamentable estado ilustran bien estas palabras: «en 1739 siguió la Marina en el mismo estado de miseria, atenida a cortos socorros que de tiempo en tiempo recibía» ${ }^{15}$. El propio Almirantazgo, haciéndose eco de las quejas de los intendentes de Marina ante la imposibilidad de poder llevar a cabo los armamentos de escuadras previstos en sus respectivos departamentos por la falta absoluta de medios, denunció, por mano de su secretario, la dramática situación operativa al secretario de Estado, marqués de Villarias:

lejos de tener preparadas nuestras escuadras para obrar en la América, ni aun en Europa lo pueden practicar en el todo (...) Faltan víveres, pertrechos y materiales. Hay muchos enfermos entre la gente de mar, estando la tropa de Marina en carnes vivas y los oficiales en la última miseria porque a todos se les deben los sueldos ${ }^{16}$.

Para financiar la guerra y paliar esta penosa realidad de la Armada se solicitó un crédito de un millón de pesos sencillos al Consulado gaditano. Los comerciantes, alegando falta de numerario, en un principio solo pudieron poner a disposición del monarca 500.000 pesos con un premio del $8 \%$ sobre los efectos embarcados en la flota que se disponía a zarpar en el otoño de 1739 hacia Veracruz, acordando conseguir la cantidad restante en otras plazas comerciales. Este segundo pago se afianzaría con los primeros caudales que llegaran de Indias ${ }^{17}$.

$\mathrm{Y}$ es que, de una forma prudente, como si en aquellos momento la guerra todavía fuera una remota posibilidad y, sobre todo, para evitar que se filtraran los proyectos y preparativos al plenipotenciario británico, Benjamin Keene, y a sus espías en los principales puertos españoles ${ }^{18}$, Ensenada había puesto en marcha la maquinaria de la guerra en la primavera de 1739 , medio año antes de la declaración oficial por parte de Inglaterra, pidiendo reservadamente a los intendentes de Marina los listados de los buques de sus respectivos departamentos

14. AGS, SSH, leg. 409. Juan Bautista de Iturralde a José de la Quintana, 1 de mayo de 1739. Citado en Perona Tomás, D.: Los orígenes..., pp. 126 y 183 (nota 300).

15. Museo Naval de Madrid [en adelante MNM], mss. 471, fol. 11. «Resumen de las consignaciones señaladas a la Marina desde 1728 a 1807 con otras noticias interesantes que ilustran el expediente».

16. Archivo Histórico Nacional [en adelante AHN], Estado, leg. 3224. Ensenada a Villarias, Aranjuez, 14 de mayo de 1739.

17. MNM, mss. 471, fol. 12 .

18. Lo cierto es que estos primeros preparativos no trascendieron: «Keene obtained the best intelligence he could about Spain military preparations and though early warnings were sent to the Caribbean, he found no other significant preparations and thought there was little to fear from the Spanish fleet». Woodfine, P.: Britannia's Glories. The Walpole Ministry and the 1739 War with Spain. Boydell \& Brewer Ltd. Nueva York, 1998, p. 140. 
y su disponibilidad para navegar «para en vista de ellas hacer juicio formal de lo que se podría preparar» ${ }^{19}$. Así pues, el Almirantazgo tomó la iniciativa, y en febrero de 1739, por la vía reservada, Ensenada pidió al asentista de víveres de la Armada, Miguel de Arizcun, y a los tres intendentes de Marina que los factores del asentista en los departamentos marítimos elaboraran un estado exacto de las provisiones excedentes del total de las 500.000 raciones de armada ordinarias que estaba obligado a proveer, para «las urgencias que puedan acaecer» ${ }^{20}$. La respuesta de Arizcun no se hizo esperar. Al día siguiente Ensenada la tenía en sus manos, acompañada de un estado que comprendía también todos los géneros que estaban comprados, pendientes de ser transportados a su destino. Cuando tuvo la confirmación de que había suficientes víveres disponibles para el consumo ordinario, además de algunos excedentes para raciones extraordinarias, Ensenada empezó a tantear las posibilidades reales de armar una gran escuadra con el intendente de Marina gaditano. En concreto había pedido a Francisco de Varas que procediera a un «supuesto» armamento de 12 de los navíos que estaban en Cádiz y los bastimentara con tres meses de víveres, confirmándole que para ello ya se habían encargado al asentista las 445.000 raciones extraordinarias necesarias ${ }^{21}$.

La ración de armada ordinaria había sido fijada por José Patiño en las Ordenanzas para la Marina que había promulgado en 1717. En ellas se señalaba que los domingos, lunes, martes y jueves se debía comer carne salada o tocino, los miércoles y viernes bacalao o queso y el sábado queso, todo ello acompañado de menestras hechas con arroz, garbanzos, frijoles, chícharos o habas, bizcocho, vino, aceite, vinagre y sal. Con la intención de ofrecer la cantidad apropiada, las instrucciones distinguían el peso de cada alimento según estuviera crudo o cocido y prescribían las cantidades a servir de cada alimento, así como la forma en que debían cocinarse. Todos los días se suministraban 18 onzas de bizcocho, un cuartillo y medio de vino; los días que tocaba carne se suministraban 8 onzas de carne salada o 5 onzas de tocino, acompañados, dos días de 2 onzas de menestra, mitad de arroz, mitad de garbanzos, y los días restantes de 3 onzas de frijoles, chícharos o habas. Para cocinar se proporcionaba una azumbre de agua, libra y media de madera rajada, sal, aceite y vinagre. La dieta de pescado consistía en 35 onzas de bacalao; la de queso, en 42 onzas de queso. Ambas dietas se servían con el mismo acompañamiento que la de carne. Cuando la navegación impedía encender los

19. AGS, Secretaría de Marina [en adelante SM], leg. 434, «Noticia de los bajeles que presentemente están armados en Cádiz, de los ya carenados y se están carenando para armarse» (s. f.).

20. AGS, SM, leg. 600, Marqués de la Ensenada a Miguel de Arizcun, Francisco de Varas, Bernardino Freyre y Alejo Gutiérrez de Rubalcaba. Madrid, 26 de febrero de 1739.

21. AGS, SM, leg. 600, Marqués de la Ensenada a Francisco de Varas, Aranjuez, 25 de mayo de 1730. 
fogones con un mínimo de seguridad, o en días de batalla, se suministraba dieta de queso y bizcocho remojado en vino y agua.

La ración de dieta se reservaba para los enfermos y heridos; constaba de 10 onzas de pan blanco, 2 onzas de sémola o de bizcocho, 8 onzas de carne fresca de carnero o un cuarto de gallina viva, un huevo, onza y media de almendras y media onza de pasas y de azúcar. Ocasionalmente también se daba carne fresca y pan blanco cuando los navíos permanecían en puerto con la intención de ahorrar el bizcocho y las carnes saladas y el tocino para las raciones durante la navegación ${ }^{22}$. Esta composición de las raciones quedó sancionada en las siguientes Ordenanzas promulgadas en 1748 , que estuvieron vigentes hasta $1793^{23}$, por lo que las raciones también se mantuvieron sin apenas variaciones durante toda la centuria. Con la salvedad, ya avanzado el siglo, de introducir el consumo de cítricos para evitar el escorbuto.

La Casa de negocios Arizcun se había hecho en 1722 con el asiento de víveres durante tres años para la Armada en la metrópoli, cuando ofertó la ración de armada por 92 maravedíes y renunció a los 100.000 escudos de anticipos que la Hacienda había hecho al anterior asentista, Antonio Punche, a cambio del arrendamiento de las rentas provinciales del reino de Granada. En 1725 Miguel de Arizcun ya estaba al frente de la Casa de Arizcun y negoció la renovación del asiento por cinco años con una rebaja de dos maravedíes en el precio de la ración, haciéndose con el arrendamiento de las Rentas Provinciales de Galicia, al que sumó en 1731 el de las Rentas de la lana ${ }^{24}$. En 1730 Arizcun consiguió una nueva renovación del asiento por otros cinco años bajando el precio un maravedí, con lo que la ración de armada quedó en 89 maravedíes. Arizcun fue incrementando su participación financiera en otros arrendamientos de rentas de la corona a lo largo de los años siguientes como compensación por los impagos de la Hacienda, convirtiéndose en un importante acreedor del Estado. En 1735, aunque Patiño había intentado promover la administración directa del Estado en la provisión de

22. MNM, Biblioteca/9419, Ordenanzas e Instrucciones que se han de observar en el Cuerpo de la Marina de España, reimpresas en Cádiz por Gerónimo Peralta, impresor mayor, capítulo XX, pp. 62-66. Pérez Fernández-Turégano, C.: Patiño y las reformas de las Administración en el reinado de Felipe V. Ministerio de Defensa, Madrid, 2006, pp. 107. Torres SÁnChEZ, R.: «Los Navarros...», pp. 225.

23. Ordenanzas generales de la Armada naval. Sobre la gobernación militar y marinera de la Armada en general y uso de las fuerzas en la mar, dos volúmenes, Madrid, en la imprenta de la viuda de D. Joaquín Ibarra, 1793.

24. Con esta cesión de rentas la Hacienda trataba de compensar las elevadas deudas que tenía con la Casa de Arizcun por el asiento de víveres para la Marina. TORRES SÁNCHEZ, R.: «Servir al rey...», pp. 163-164. AQUERRETA GonZÁLEZ, S.: «Reforma fiscal y continuidad en el sistema de arrendamientos: la renta de lanas en el reinado de Felipe V» en GonzÁlez Enciso, A. (ed.): El negocio de la lana en España, (1650-1830). Eunsa, Pamplona. 2001, pp. 109-133. 
víveres, Arizcun, desde la posición de fuerza que le proporcionaba el hecho de ser acreedor, consiguió una nueva renovación del asiento para la Casa de Arizcun hasta 1740. A este fin presionó al ministro para que la Real Hacienda se hiciera cargo de todos los géneros comprados y almacenados y así evitar su ruina. La maniobra le salió muy bien, ya que en esta ocasión, no solo mantuvo el precio de la ración en 89 maravedíes, sino que también consiguió que se le volviera a hacer un adelanto mensual de 83.000 escudos (913.000 reales) $)^{25}$.

Este último asiento, por tanto, es el que estaba vigente en $1739 \mathrm{y}$, una vez dadas las disposiciones para poner en marcha el «posible» armamento, Ensenada se lo comunicó a Quintana y le pidió que se reuniera con Arizcun para oficializar el encargo de las 445.000 raciones extraordinarias. En realidad, al establecerse el asiento, la corona se había comprometido a que las peticiones de raciones las hiciera a principios de cada año directamente la Secretaría de Marina, evitando así las confusiones que podrían generarse si intervenían varios intermediarios. Así que, cumplida la formalidad contractual, el asentista se reunió con el ministro de Marina y le garantizó las entregas de víveres en las bases navales de Cádiz y Cartagena. Sin embargo no pudo comprometerse para Ferrol, que presentaba unos problemas añadidos de falta de producción local y de serias dificultades para el transporte terrestre. Arizcun explicó que sencillamente era imposible encontrar provisiones para preparar las raciones, ni en el reino de Galicia ni en sus cercanías. Por ello pidió al ministro que con un correo extraordinario se ordenase al intendente gaditano que separara las raciones que iban destinadas a Ferrol de todas las que se iban a depositar en los almacenes en Cádiz y las trasladara por mar en embarcaciones fletadas ${ }^{26}$.

A pesar de la discreción con la que se intentaba actuar para evitar que trascendieran al enemigo las medidas militares para la movilización que el gobierno español iba adoptando, para todos los implicados era evidente que España estaba a las puertas de una guerra naval. Arizcun así lo entendió y, en previsión de que la casa inglesa MacKay \& Smith, asentada en Cádiz, fuera expulsada junto al resto de los ingleses y quedarse sin su proveedor de carnes saladas y tocinos, importados por estos comerciantes de Irlanda porque no se producían en España, presentó un memorial al Almirantazgo, solicitando que, en caso de guerra, se considerase estratégica la actividad de esta casa comercial y no se la obligase a abandonar

25. Torres SÁnchez, R.: «Los navarros...», pp. 234-246. Sobre la Casa de Arizcun: Aquerreta GoNZÁlEZ, S.: «La Casa de Arizcun 1725-1742: las estrategias financieras de un hombre de negocios en el Madrid de la Ilustración» en Ferrer Benimeli (dir.); SARAsa, E., SERrano, E., (coords.), Congreso Internacional El conde de Aranda y su tiempo. Diputación de Zaragoza, Zaragoza, 2000, vol. 1, pp. 659-678.

26. AGS, SM, leg. 600, Ensenada a Quintana, 18 de mayo de 1739. La respuesta de Quintana escrita y firmada en el margen el 19 de mayo de 1739. 
el territorio español. Ensenada escribió a Varas, quien además de intendente general de Marina era presidente de la Casa de la Contratación, preguntándole si había algún antecedente y si veía algún inconveniente en acceder a la petición del asentista. No obstante, temiendo que la resolución de este asunto se retrasara le ordenó: «Deberá en este caso no esperar la determinación del rey o de S.A., sino ejecutar lo que sea costumbre y más conveniente al Real Servicio, dando después cuenta de ello» ${ }^{27}$.

Entre tanto le llegaba la respuesta de Varas, Ensenada trató de ganar tiempo trasladando la petición de Arizcun con la aprobación del Infante-Almirante, por mano del marqués de Villarias, al rey. También, haciendo uso de su pragmatismo, pidió a los intendentes de marina que ahorraran la carne salada y el tocino para las raciones de mar, ordenando que, mientras los buques permanecieran atracados en sus respectivos puertos, se sustituyeran estos productos por carne fresca cuatro días a la semana y por bacalao los tres restantes ${ }^{28}$.

Varas informó de la existencia de dos precedentes excepcionales. El primero había sido protagonizado por los ministros de los Galeones en Tierra Firme, quienes, ante la ausencia total de harinas para fabricar el bizcocho y las dificultades para llevarlas desde La Habana o Veracruz, las habían comprado directamente en Jamaica. La segunda excepción había ocurrido durante la guerra contra Inglaterra de 1727, cuando se expidió por la vía reservada una orden al gobernador de Cádiz para que permitiera al comerciante Guillermo Yak y a otros importar varios cargamentos de arboladuras y maderas de construcción del Norte. Basándose en estos antecedentes y, sobre todo, mirando por la contingencia de la guerra y por el ahorro de la Hacienda, Varas se mostró muy favorable a que se hiciera una excepción con la casa MacKay \& Smith. Sin embargo, no tomó ninguna iniciativa al respecto, como le había ordenado Ensenada, por no haber encontrado ningún antecedente justificativo de que los intendentes de Marina hubieran tenido la facultad de exceptuar a alguien del cumplimiento de una resolución real. Evidentemente no quiso entrar en conflicto con el capitán general de Andalucía, quien ostentaba la máxima jurisdicción ${ }^{29}$.

El dictamen del rey se retrasaba y, entre tanto, se promulgó la expulsión del territorio nacional de todos los súbditos británicos. Cuando, mediante un bando, se tuvo noticia de ello en Cádiz, el factor del asentista, Manuel Antonio de Pereda, escribió a Varas pidiéndole que intercediera ante el capitán general de Andalucía.

27. Ibidem. Ensenada a Varas, San Ildefonso, 10 de agosto de 1739. Adjunta una copia del Memorial de Miguel de Arizcun, con la solicitud.

28. Ibídem. Ensenada a Villarias, San Ildefonso, 15 de agosto de 1739. Ensenada al conde de Bena y Masserano, (comandante del departamento marítimo de Cartagena), San Ildefonso, 31 de julio de 1739.

29. Ibídem, Varas a Ensenada, Cádiz, 25 de agosto de 1739. 
Varas así lo hizo y, en vista de que la cuestión se hallaba pendiente de resolución real, el conde de Le Roydeville concedió a la casa MacKay \& Smith un plazo de gracia de veinte días ${ }^{30}$. En el ínterin Ensenada había hecho llegar a Villarias la información aportada por Varas. Para presionar hacia una resolución real favorable a la permanencia de MacKay \& Smith en Cádiz, le indicaba que por los artículos 13 y 24 del contrato de asiento la Real Hacienda estaría obligada a indemnizar al asentista por las pérdidas que tuviera «por causa de enemigos». Este último argumento fue decisivo para resolver favorablemente la petición de Arizcun ${ }^{31}$.

Otro privilegio que se concedió por estas fechas a Arizcun, fue que las embarcaciones extranjeras que había fletado para transportar los víveres hasta Cartagena y Ferrol lo hicieran sin pagar los correspondientes derechos. Ensenada pidió expresamente a los intendentes de Marina que, una vez descargados los víveres, diesen a los barcos que los transportaban todo tipo de facilidades para su salida del puerto $^{32}$. De igual modo, Arizcun presentó una solicitud para que se exceptuaran del embargo general decretado sobre todo tipo de embarcaciones que pudieran servir a la Armada como avisos, transportes, bombardas, etc., las que él necesitaba para el transporte de víveres. Arizcun argumentó que eran imprescindibles para llevar a Ferrol con la diligencia requerida las provisiones que tenía almacenadas en Cádiz, Bilbao y San Sebastián. El Almirantazgo así lo entendió y Ensenada ordenó a los intendentes de Marina de esas poblaciones que fletaran ellos los barcos necesarios en dichos puertos ${ }^{33}$.

A partir de septiembre, cuando ya era evidente que ambas naciones estaban en guerra, por haber incumplido, tanto la Compañía del Mar del Sur como el gobierno de España, los plazos pactados para el pago de sus respectivas deudas ${ }^{34}$, el Almirantazgo, en previsión de lo que el monarca decidiera hacer con los buques de la Armada, le propuso enviar las escuadras de Cádiz y Ferrol a patrullar las costas peninsulares. El rey, en un principio, aprobó la propuesta, y Ensenada ordenó a los comandantes de los departamentos marítimos de Cádiz y Ferrol que «no solo estén prontos para salir repentinamente a obrar todos los navíos y fragatas, siempre que S.M. lo mande, sino que duerman a bordo todas las noches desde el capitán hasta el último paje de escoba». Sin embargo, esta primera movilización

30. Ibídem, Manuel Antonio de Pereda, director de víveres de Marina, al intendente general de Marina, Francisco de Varas y Valdés. Cádiz, 11 de septiembre de 1739, el conde de Le Roydeville a Francisco de Varas y Valdés. Cádiz, 15 de septiembre de 1739, Varas y Valdés a Cenón de Somodevilla.

31. Ibídem, San Ildefonso, 9 de septiembre de 1739, Cenón de Somodevilla al marqués de Villarias. En una nota enmarcada al margen de la carta puede leerse: «Arreglado al dictamen de Varas y citándole pedir por un papel al Sr. Villarias el salvoconducto».

32. Ibidem. San Ildefonso, 29 de agosto de 1739, Cenón de Somodevilla a Bernardino Freyre y Francisco de Liaño.

33. Ibídem.

34. Bethencourt Massieu, A.: Relaciones de España..., pp. 507-517. 
naval no fue utilizada por el gobierno con la diligencia que los marinos de la Junta del Almirantazgo esperaban, ya que las escuadras permanecieron inactivas en sus respectivos puertos sin recibir las órdenes de zarpar ${ }^{35}$.

Cuando a principios de noviembre llegó a la corte la declaración oficial de guerra de Inglaterra, proclamada por Jorge II el 23 de octubre, el gabinete ministerial español formó una Junta de Guerra presidida por el duque de Montemar con el objetivo de discurrir la estrategia a seguir. Los tres miembros de la Junta de Marina del Almirantazgo, los tenientes generales, marqués de Mari y Francisco Cornejo y el jefe de escuadra Rodrigo Torres no participaron directamente en esta Junta de Guerra. Solamente se pedía su opinión en cuestiones relacionadas con la logística de las escuadras, y siempre por mano del ministro de Marina. Este trasiego de correspondencia, que iba y venía de la Secretaría de Estado a la de Marina y de esta al Almirantazgo, retrasaba la toma de decisiones en un momento en el que ganar tiempo podía ser decisivo, máxime cuando se sabía que Inglaterra desde la primavera había desplegado varias escuadras. La primera en mayo, al mando del almirante Haddock en el Mediterráneo para defender sus bases navales en Gibraltar y Menorca y vigilar los puertos de Cádiz y Cartagena. Mientras tanto, el almirante Ogle tenía desde julio sus unidades cruzando entre Cádiz y las islas Azores y a lo largo de la costa de Galicia para obstaculizar las derrotas a Indias, tratando de interceptar cualquier navío que viniera de Indias con caudales o impedir la salida de refuerzos navales desde Cádiz o Ferrol ${ }^{36}$. Pero la peor consecuencia de ignorar a los marinos es que en la elaboración de los planes estratégicos no se contaba con voces que hicieran valer la utilidad operativa de los navíos de la Armada.

Las primeras decisiones de la Junta de Guerra, cuando recibió la información sobre las escuadras británicas, se centraron en cancelar la salida de la flota de la Carrera hacia Nueva España, que en un principio se había previsto para finales de noviembre, y en enviar la Capitana y la Almiranta de la flota hacia Veracruz cargadas con azogues, así como pertrechos navales para recambios de Galeones, que se hallaban resguardados en Cartagena de Indias esperando la llegada de la Flota del Perú a Panamá poder hacer la feria en Portobelo, y para la Armada de Barlovento. Además de los dos navíos de guerra, debían fletarse dos tartanas para que fueran también a Veracruz llevando azogues, ya que un aviso enviado por el virrey de Nueva España había traído la noticia de que solo quedaba mercurio para el beneficio de la plata hasta diciembre. Con seis de los doce navíos que había

35. AGS, SM, leg. 434, San Ildefonso, 10 de septiembre de 1739, Ensenada a Quintana, 12 de septiembre de 1739, Villarias a Quintana, y 14 de septiembre de 1739, Ensenada al marqués de Torreblanca y a Francisco de Liaño.

36. HaRding, R.: The Emergence..., pp. 65-66. 
destacados en Cádiz decidieron formar una escuadra para destinarla al Mediterráneo, reforzando la actividad de los tres navíos y dos fragatas que estaban operativos en la base de Cartagena. Su misión era oponerse a la escuadra del almirante Haddock. Para la defensa del área caribeña destinaron dos navíos de la escuadra de Ferrol, que transportarían tropas de refuerzo, marinería y pertrechos para armar otros dos navíos recién construidos en el arsenal de La Habana. A estos cuatro navíos se unirían los dos que transportaban los azogues desde Cádiz, una vez los hubieran descargado en Veracruz, formando todos juntos una escuadra de seis navíos de línea (uno de 80 cañones, tres de 70, uno de 60 y uno de 50). Este escuadrón quedaría destacado en La Habana para oponerse al del comandante Charles Brown con sede en Jamaica ${ }^{37}$.

El desequilibrio de fuerzas destinadas a las distintas partes del Imperio evidencia que en esos momentos la Junta de Guerra daba prioridad a la defensa de los territorios en el Mediterráneo, las islas Baleares y los reinos italianos de Nápoles y Sicilia. Lo cual se explica por las negociaciones diplomáticas que se estaban llevando a cabo con Francia para conseguir su apoyo para la guerra contra Inglaterra y contra Austria con la intención final de garantizar el ducado de Parma al Infante-Almirante ${ }^{38}$. La estrategia de la Junta de Guerra también intentaba sembrar intranquilidad en el gabinete inglés acerca de las intenciones hacia Gibraltar y Menorca, obligándoles a destinar varias escuadras para su defensa, como así hicieron $^{39}$. Sin embargo, los miembros de la Junta de Guerra, que no eran marinos y desconocían las posibilidades de la táctica naval, pensaban que el simple hecho de mantener gran parte de la flota española inmovilizada en Cádiz y en Ferrol, obligaría a los ingleses a «entretener» una voluminosa escuadra en aguas europeas, evitando que pasaran a Indias. También evidenciaron su desconocimiento de la realidad americana, al asumir que la defensa del extenso ámbito caribeño podía dejarse en manos de una escuadra de seis navíos y de los corsarios que armaban los gobernadores de las plazas americanas ${ }^{40}$.

37. AGS, SM, leg. 434, José de la Quintana a Cenón de Somodevilla, Buen Retiro, 23 de noviembre de 1739 .

38. Ozanam, D.: «La política exterior de España en tiempo de Felipe V y de Fernando VI», en Historia de España de Ramón Menéndez Pidal, t. XXIX. Madrid, 1985, pp. 623-625.

39. Gual Truyol, S.: La expedición de Mahón, 1738-1741. Museo Histórico Militar de Menorca, 1993, pp. 18-20. Bethencourt Massieu, A.: Relaciones..., p. 583.

40. El marqués de la Mina escribió: «Nosotros solos bastamos a defendernos y destruir su poder con armadas y sin el empeño de grandes flotas». AHN, Estado, leg. 4145, Mina a Villarias, París, 29 de septiembre de 1739, citado en HiLTON, S. L.: «El conflicto anglo-español en Florida: utopía y realismo en la política española, 1732-1739», Quinto Centenario. Revista Complutense de Historia de América, 5, 1983, pp. 97-130, la cita en p. 126. El embajador británico Benjamin Keene informó en este sentido al secretario de Estado para los asuntos del Sur, Newcastle, recomendándole que los ataques de las escuadras inglesas se centrasen en América: «America, therefore, my lord, is where we can do them much and important damage». Harding, R.: The Emergence..., pp. 30-31. AGS, SM, 
Ni los marinos de la Junta del Almirantazgo, ni su secretario, Ensenada, estaban de acuerdo con un sistema tan poco operativo de toma de decisiones, ni con algunas de las medidas defensivas acordadas por la Junta de Guerra porque descuidaban la defensa de las Indias. Cuando recibieron las órdenes para aprontar con la mayor brevedad posible los cuatro navíos de guerra más las dos tartanas y todos los géneros que se necesitaban para armar los dos nuevos navíos de La Habana, Ensenada, siempre en nombre del Infante-Almirante, respondió a Quintana proponiéndole, primero, que los marinos de la Junta del Almirantazgo participaran directamente en las reuniones de la Junta de Guerra y, en segundo lugar, presionándole para que pidiera al ministro de Hacienda caudales para poder financiar los armamentos previstos, argumentando que «solo la falta de este (dinero) podrá diferir en Cádiz la salida de los dos navíos y atrasar la de los de Ferrol».

Ensenada, quien con no poco esfuerzo había conseguido tener armados y avituallados para tres meses a la gran mayoría de los navíos y fragatas de la Armada, iba un paso por delante de las decisiones del gabinete, como se desprende de su respuesta a Quintana. Había organizado el cometido de cada una de las unidades navales movilizadas, nombrado a sus oficiales, distribuido la carga que cada navío debía transportar; incluso había preparado varios presupuestos con los gastos para armar más escuadras y aportaba sugerencias al respecto. Para este trabajo lo más significativo de su actividad logística es la defensa que hizo de los asentistas, a quienes dijo no se podía culpar de la carencia de todo tipo de pertrechos en los almacenes de la Armada ni de que exigieran un adelanto para las compras de géneros, «pues se han esforzado a más de lo que debían, respecto lo mal que se les paga ${ }^{41}$. Recordemos que, debido a la suspensión de pagos decretada, todos ellos arrastraban una importante deuda con la Real Hacienda.

En los primeros días de diciembre llegaron a la corte varias cartas del comisario de Marina de La Habana, Lorenzo Montalvo, y del gobernador de la plaza, Francisco de Güemes y Horcasitas, enviadas en un aviso, informando de que se había visto patrullando por los alrededores de la isla a varios navíos ingleses. Algunos habían desembarcado en Bahía Honda para hacerse con víveres y habían cañoneado el fuerte de Bacuranao. Estas noticias confirmaban los datos que había aportado el embajador español en Londres, Tomás Geraldino, sobre el envío a

leg. 434, Quintana a Ensenada, Buen Retiro, 26 de noviembre de 1739. AGS, SM, leg. 397, docs. 89 y 117. Villarias a Quintana, 21 de noviembre y 6 de diciembre de 1739.

41. AGS, SM, leg. 434, Ensenada a Quintana, Buen Retiro, 25 de noviembre de 1739 y 6 de diciembre de 1739. En el presupuesto adjuntado la suma para armar los seis navíos destinados a América ascendía a 5.785.175 reales de vellón, de los que 3.140.550 reales correspondían a la partida de pertrechos necesarios para armar los nuevos navíos de La Habana, los repuestos de los dos navíos que protegían a los galeones, los de la escuadra de Barlovento y los de la nueva escuadra de seis que se destacaba en La Habana. 
Jamaica de la flota del almirante Vernon durante el verano de $1739^{42}$. Ante estas noticias los generales de Marina volvieron a pedir reunirse con los miembros de la Junta de Guerra para exponerles su propuesta de defensa de las Indias: si el rey seguía pensando en no utilizar por el momento los siete navíos destacados en Ferrol para alguna misión en Europa, proponían enviar cuanto antes una escuadra a La Habana formada con seis de ellos, y volvían a urgir, una vez más, a que se facilitaran los caudales para que los asentistas pudieran comprar los géneros necesarios para armar los navíos ${ }^{43}$.

Mientras se negociaba con Francia su posible participación en la guerra, todavía llevó unos meses concretar la estrategia a seguir. En el ínterin Ensenada tuvo en cuenta que la mayoría de los buques llevaban armados y avituallados desde mediados de septiembre y que, por lo tanto, convendría revisar el estado de los víveres más perecederos (las carnes y los tocinos) que las tripulaciones no estaban consumiendo, guardándolos para cuando tuvieran que salir a navegar. Ensenada encargó al intendente de Ferrol, Bernardino Freyre, que procediera a revisarlos y, por el mismo motivo, que se fuera consumiendo el bizcocho que Arizcun iría reemplazando según su contrato ${ }^{44}$.

El rey, por indicaciones del duque de Montemar, a principios de enero había cambiado las órdenes dadas inicialmente, disponiendo ahora que no se despachara ningún navío a Indias ${ }^{45}$. La idea del rey, avalada por la Junta de Guerra, era formar una gran flota con las fuerzas navales destacadas en Cartagena y gran parte de las de Cádiz para actuar en el Mediterráneo, reservando los navíos de Ferrol para mantener la incertidumbre sobre una posible expedición a Inglaterra en apoyo de la causa jacobita.

Sin embargo, cuando a mediados de enero llegó la noticia del ataque de Vernon a Portobelo, los marinos de la Junta pudieron convencer al duque de Montemar de la imperiosa necesidad de enviar refuerzos navales al Caribe. Su proyecto era unir las fuerzas que se enviaran desde España a las que mantenía Blas de Lezo

42. Ibídem, Ensenada a Quintana, 6 de diciembre de 1739. Ibídem. «Nota que ha dado D. Tomás de Geraldino después que llegó a esta corte de los navíos de que se compone la escuadra del mando del almirante Vernon que pasó a la Jamaica» (s. f.). La escuadra se componía de cinco navíos y una fragata. «Lista de los navíos de guerra y fragatas que había en Jamaica el 30 de junio». Esta nueva escuadra reforzaba la que se hallaba destacada en Jamaica al mando del comandante Brown que se componía de siete navíos y cinco embarcaciones menores. Ibídem, Quintana a Ensenada, 9 de diciembre de 1739.

43. Ibídem. Dictamen de la Junta de Marina del Almirantazgo, marqués de Mari, Francisco Cornejo y Rodrigo Torres, 12 de diciembre de 1739. También en AGS, SM, leg. 397, doc. 101.

44. AGS, SM, leg. 600, Ensenada a Bernardino Freyre, Buen Retiro, 25 de noviembre de 1739. El 10 de noviembre Ensenada había avisado a Arizcun que tenía que mantener un repuesto de 500.000 raciones en Ferrol. Ibídem, Ensenada a Arizcun, Aranjuez, 4 de mayo de 1740.

45. AGS, SM, leg. 397-1, fol. 117. Villarias a Quintana, 6 de enero de 1740. 
en Cartagena de Indias, formando una gran escuadra que pudiera hacer frente a las inglesas que estaban siendo reforzadas con más unidades después del éxito inicial de Vernon. En concreto, la nueva propuesta del Almirantazgo contemplaba despachar seis navíos del departamento gaditano hacia Ferrol para unirlos a seis de los que estaban allí destinados, formando una gran escuadra de 12 navíos. Los ocho navíos y las cuatro bombardas que todavía quedaban en Cádiz se habilitarían y armarían en previsión de cualquier incidente y en el ínterin obligarían a los ingleses al «gasto de una escuadra en los mares del mismo Cádiz». Convencido finalmente Montemar de las ventajas estratégicas del proyecto de los marinos, indujo al rey a que cambiara de opinión y ordenara la puesta en marcha de la expedición naval. Por expreso deseo del monarca, en el diseño de la campaña solo intervinieron los marinos de la Junta y el duque de Montemar, dentro del mayor sigilo para evitar cualquier filtración que pudiera llegar al enemigo. El mando de la escuadra le entregó a uno de los miembros de la Junta de Marinos: al jefe de escuadra Rodrigo Torres.

Cuando a Ensenada se le ordenó poner en marcha la logística para el armamento de esta flota de guerra, lo primero que hizo, una vez más, fue pedir dinero porque:

continuando el abandono que se experimenta de la Marina, no obstante la determinación del rey para que sea preferida a las demás urgencias de la Monarquía, no es dudable en opinión de los referidos ministro de la Guerra y tenientes generales que lejos de poder ponerse en práctica este proyecto y los de Galicia y Cartagena, se espera por instantes la lamentable noticia de haberse deshecho los tales cuales armamentos, de cuyos gravísimos perjuicios y los que ya se están tocando con las manos, nunca será responsable el Almirantazgo, respecto haber reiteradas veces representado anunciándolos ${ }^{46}$.

Debido al elevado número de tropas desplazadas a Galicia para reforzar su defensa ante un posible ataque anfibio ${ }^{47}$, todos los edificios disponibles en La Coruña y en Ferrol habían sido destinados a alojar a los soldados. Por este motivo Miguel de Arizcun se encontró sin inmuebles apropiados para almacenar la gran cantidad de víveres que había comprado, sobre todo el trigo, la harina, el bizcocho y el queso, que eran los más perecederos ante la humedad. Por el artículo 18 del asiento, podía disponer de los almacenes existentes en los parajes donde debía entregar las raciones, poniéndose de acuerdo con el intendente de Marina de la zona. Sin embargo, no pudo llegar a un acuerdo con Bernardino Freyre, quien se negó en rotundo a cederle algunos edificios desocupados en las inmediaciones

46. AGS, SM, leg. 434, Ensenada a Quintana, Buen Retiro, 19 de enero de 1740.

47. En el informe sobre las medidas defensivas de la corte española, que Benjamin Keene envió a Newcastle poco antes de abandonar España, calculaba que se habían enviado 7.000 hombres a Galicia. Harding, R.: The Emergence..., pp. 30-31. 
del puerto de Ferrol, argumentando que se «infestarían de ratones». Arizcun recurrió al Almirantazgo y Ensenada tomó cartas en el asunto. Escribió a Freyre pidiéndole que, mientras durase el armamento de la flota, pusiera a disposición del apoderado de Arizcun, Nicolás de Miguel, los almacenes o las partes de ellos que tuviera desocupadas. Freyre no se amilanó y contestó a Ensenada que lo haría gustoso pero solo para guardar el vino, las carnes y tocinos salados y el aceite en barricas, porque el bizcocho, los cereales y los quesos atraían muchas ratas que destrozaban las velas y las jarcias, como ya había ocurrido en otras ocasiones. Eso sí, consciente de que no se trataba de una cuestión baladí, se comprometió a buscar una solución intermedia ${ }^{48}$.

Para reunir en Ferrol los 12 navíos de guerra que debían formar la flota destinada al Caribe, como hemos dicho, se había ordenado al teniente general Manuel López Pintado ${ }^{49}$, comandante del departamento gaditano, llevar una escuadra de seis navíos desde Cádiz a Ferrol. Durante la navegación apresaron tres embarcaciones inglesas que se dirigían a Gibraltar cargadas con bizcocho y vino para la escuadra inglesa del almirante Haddock. Cuando esta noticia le llegó a Arizcun, no dudó en solicitar al Almirantazgo que se le diera un trato preferente frente a otros posibles interesados en comprar la carga de las presas, pujando por ella a su justo precio a cuenta de sus crecidos descubiertos. Seguro de que no se le iba a negar esta gracia, Arizcun pidió en su memorial llanamente que el intendente gaditano entregara los géneros apresados a su apoderado en Ferrol, quien le firmaría el correspondiente recibo para que en la Contaduría Principal de Marina se lo descontaran de las justificaciones de consumos y repuestos. Ensenada era plenamente consciente de las dificultades que Arizcun estaba encontrando en la conducción de los víveres a causa de la guerra y valoraba especialmente el esfuerzo que el asentista estaba haciendo para bastimentar las escuadras de la Armada a pesar del enorme descubierto que arrastraba, así que no dudó en aprobar la solicitud de Arizcun, dando la orden correspondiente a Freyre. También ordenó al intendente de Marina de San Sebastián, Manuel de las Casas, que entregara el vino que conducía una embarcación apresada en las mismas fechas por un corsario vasco al apoderado de Arizcun y que le diera preferencia para la compra de los víveres de todas las presas que entrasen en aquel puerto ${ }^{50}$.

Buena prueba de las dificultades que conllevaba la planificación de las compras de los distintos productos que formaban las raciones, así como de las rigideces

48. AGS, SM, leg. 600, Arizcun a Ensenada, s.f. Ensenada a Freyre, Buen Retiro, 16 de marzo de 1740. Freyre a Ensenada, Graña, 29 de marzo de 1740.

49. Tapias Herrero, E.: «El Teniente general López-Pintado, cargador a Indias, jefe de escuadra y marqués de Torreblanca del Aljarafe», Revista General de Marina, 259 (2010), pp. 409-418.

50. Ibídem, Arizcun a Ensenada, Madrid, 29 de abril de 1740. Ensenada a Freyre, Aranjuez, 3 de mayo de 1740. Ensenada a Manuel de las Casas, Aranjuez, 2 de mayo de 1740. 
de mercado, agravadas en tiempo de guerra, para la venta de excedentes es el siguiente caso que obligó a Arizcun a recurrir, una vez más, al Almirantazgo. En un nuevo memorial Arizcun pedía al Infante-Almirante una excepción más en el cumplimiento de la normativa decretada con motivo de la guerra, en definitiva un nuevo privilegio. Gracias a la concesión de dos salvoconductos había trasladado en un mercante desde Lisboa a Cádiz una gran cantidad de bacalao comprado en Inglaterra del que tenía todavía almacenados en Cádiz 2.000 quintales, que corrían un serio riesgo de echarse a perder debido al bajo consumo que de este producto en aquellos momentos hacía la Armada. Arizcun pedía que se le liberase de la prohibición general decretada de vender artículos de origen inglés y que se permitiese a su apoderado poner 1.000 quintales a la venta en la ciudad de Cádiz, pagando los correspondientes derechos. De esta forma podría compensar los gastos hechos para la compra y conducción del bacalao. Una vez más la solicitud fue aprobada por el Almirantazgo y se hizo la excepción ${ }^{51}$.

Ensenada, a principios de mayo, hizo un encargo extraordinario a Arizcun para avituallar la flota de Torres, pidiéndole que pusiera en Ferrol «con la brevedad posible» otro millón de raciones extraordinarias, además del medio millón que ya se le habían encargado en noviembre para repuestos. Por requerimiento de Arizcun quien, debido a las deudas que había ido acumulando por los impagos de la Real Hacienda ${ }^{52}$, se negó a aprontar el nuevo encargo si no se le anticipaba algún dinero, Ensenada escribió al nuevo ministro de Hacienda, Fernando Verdes Montenegro en una forma que podía hacerle sentirse responsable de las consecuencias de una nueva negativa a proveer fondos para la Armada. Le exponía la cuestión claramente: «no habiendo arbitrio para diferir un instante, cuanto más para suspender las providencias (...) para poner en práctica una resolución secreta e importantísima que el rey ha tomado». Su intención, además de que socorriera al asentista con algún dinero del mucho que se le estaba debiendo, era dejarle claro que estaba incumpliendo las órdenes del rey para liberar fondos: «no pudiendo negarse a Arizcun la justa razón con que clama ser socorrido y corta extinción que se la ha señalado, no obstante las reiteradas órdenes de S.M. ${ }^{53}$ ».

51. Ibídem, Arizcun a Ensenada, 4 de mayo de 1740. Ensenada a Varas, Aranjuez, 5 de mayo de 1740 .

52. Cuando se produjo la suspensión de pagos en 1739, Arizcun ya acumulaba una deuda de 17 millones de reales. IBÁNEZZ MOLINA, J.: Rentas provinciales, administración real y recaudadores en el reinado de Felipe V, (1700-1739), Universidad de Granada, Granada, 1986, p. 358, citado en TORRES SÁNCHEZ, R.: «Los navarros...», p. 246.

53. AGS, SM. leg. 600, Ensenada a Arizcun y Ensenada a Verdes Montenegro, 6 de febrero de 1740. «Nota de las raciones y géneros de víveres que además de los referidos repuestos ordinarios se han mandado poner en El Ferrol y ha de aprontar en aquel puerto D. Miguel de Arizcun de extraordinario. 500.000 raciones enteras de armada, 500.000 más sin vino, 875.000 quintales de harina flor embarrilada, 2.500 quintales de menestra fina y en defecto 3.750 de la ordinaria, 2.230 arrobas de 
La causa del grandísimo descubierto en que se hallaba Arizcun estaba en las medidas de ahorro decretadas por Iturralde, el antecesor de Verdes Montenegro, por las que había asignado una pequeña cantidad para ir pagando las compras de víveres que necesitaba, política económica que Verdes Montenegro había mantenido, a pesar de que el rey le había ordenado que no ahorrase a costa de la Armada.

Pero Arizcun no solo tenía problemas económicos para seguir financiando la provisión de víveres de la Armada por el descubierto que arrastraba. Sus proveedores ya no le fiaban como él mismo exponía elocuentemente: «por la desconfianza con que viven los correspondientes, de cobrar sus desembolsos respecto la espera que les he pedido para el pagamento de los que tienen hechos». Es decir, él mismo había incumplido los plazos de pago acordados con sus proveedores, lo que ahora le impedía volver a hacerles un pedido fundamentado en una confianza que ya no tenían, y la única forma de recuperarla era pagando.

A este problema financiero se sumaba otro logístico. Debido a la guerra le resultaba casi imposible traer las carnes y tocinos salados de su proveedor habitual en Irlanda y en el reino de Galicia no se encontraban ni harinas, ni menestras, ni aceites, ni vinagres, por lo que, incluso contando con un pago adelantado, no podía aventurar cuándo podría entregar las raciones en Ferrol ${ }^{54}$. Esta realidad fue utilizada para forzar a Verdes Montenegro y a la Junta de Hacienda a que adelantaran algún dinero a Arizcun. No obstante, Ensenada le pidió que, independientemente de las gestiones que él mismo estaba haciendo, se reuniera con Quintana y le expusiera la situación. Como era previsible, la reunión con el ministro de Marina para Arizcun fue muy decepcionante, «quedando todo en promesas». Ensenada también estaba presionando al ministro directamente y, convencido de que su intervención con Quintana había tenido éxito, pidió al asentista que acudiera otra vez a hablar con Quintana, quien en esta segunda entrevista pidió a Arizcun que «volviera el miércoles o el jueves». El fruto de tanta presión y de tanta paciencia fue que Quintana, finalmente, pudo librar a Arizcun 300.000 escudos a cuenta de los más de 600.000 que importaba el pedido extraordinario de raciones para la flota de Torres. Según Quintana, la cantidad restante se le iría pagando cuando fuera presentando los correspondientes recibos de haber entregado los géneros en Ferrol. Este adelanto fue posible gracias al crédito de un millón de pesos (15.000.000 reales de vellón) concedido por el Consulado gaditano, que se esperaba entrara en la Depositaría de Indias por aquellos días ${ }^{55}$.

aceite, 2.860 de vinagre, 1.428 quintales de carne y 1.096 de tocino. Que todos estos víveres importarán con corta diferencia 383.000 escudos de vellón». Aranjuez, 6 de mayo de 1740.

54. Ibidem, Arizcun a Ensenada, Madrid, 5 de mayo de 1740.

55. Ibídem, Ensenada a Arizcun, Aranjuez, 6 y 8 de mayo de 1740. Arizcun a Ensenada, Madrid, 7 y 9 de mayo de 1740. Ensenada a Quintana, Aranjuez, 28 de mayo de 1740, Quintana a Ensenada, 29 de mayo de 1740. Quintana a Arizcun, Buen Retiro, 11 de junio de 1740. Quintana a Varas, Buen Retiro, 11 de junio de 1740. AGS, SM, leg. 396-1, fol. 321, Ensenada a Freyre. 
Sin embargo, poco le duraron los escudos en el bolsillo a Arizcun. A finales de mayo Ensenada preguntó sutilmente a Quintana si Arizcun «se había allanado a aprontar en Ferrol las raciones extraordinarias», que era otra forma de preguntar si se le había adelantado algún dinero, ya que esa había sido desde el principio la condición del asentista para ponerse en movimiento ${ }^{56}$. Cuando a los pocos días Ensenada tuvo la confirmación de la cantidad exacta que se le iba a adelantar a Arizcun y de los plazos de pago estipulados por la Depositaría de Indias, le escribió pidiéndole el dinero en forma de un nuevo crédito. Ensenada argumentaba que el rey había resuelto que entregara el dinero al Almirantazgo para «una expedición pronta y secreta de mar». Pero no se lo pedía amablemente, le exigía que entregara «inmediatamente» a los tesoreros de Marina de Ferrol y Guarnizo el primer pago de 100.000 escudos, ya fuera en especie o en letras. Las cartas de pago que le entregarían los tesoreros de Marina le servirían como data para su crecido depósito de deuda en la Depositaría de Indias. Además, le preguntaba si Verdes Montenegro le había confirmado el pago de los 143.846 escudos restantes para completar el adelanto a lo largo de ese mes de junio y, si en su defecto, él podría suplir esa cantidad a cuenta de la libranza que de ella se le iba a hacer. Naturalmente, la motivación de Arizcun para allanarse a este nuevo préstamo forzoso la tenía que buscar en su amor y celo al rey, y la garantía de devolución en la buena fe en que se le reembolsaría el dinero conforme fueran entrando caudales en la Depositaría de Indias. Los tesoreros de la Junta de Hacienda le firmarían las correspondientes letras de pago por el concepto de aprovisionamiento de pertrechos y materiales comprados en España y fuera de ella ${ }^{57}$.

Ensenada ya había dado pruebas suficientes de sus habilidades logísticas durante la campaña de reconquista del reino de Nápoles y de las Dos Sicilias en 1734, que le había valido el título de Castilla en 1736 y el cargo de secretario del Almirantazgo desde su creación en 1737. En esta ocasión estaba tratando de armar y bastimentar la enorme escuadra de Torres, además de otra de seis navíos destinada al Mar del Sur al mando del jefe de escuadra José Pizarro, con el agravante añadido de que a causa de la política financiera restrictiva en aquellos momentos era imposible garantizar una financiación regular a la Armada, debido también a la inestabilidad de los ingresos, que dependían de los fondos que fueran entrando en la Depositaría de Indias, bien a través del crédito concedido por el Consulado gaditano, o de la plata americana que trajeran los buques de guerra que conseguían romper la vigilancia a la que la marina inglesa tenía sometidas las principales rutas marítimas y los bloqueos de los puertos de Cádiz y Ferrol. Así que no nos tiene que extrañar que Ensenada, carente de medios para armar las escuadras, echara

56. AGS, SM, leg. 600, Ensenada a Quintana, Aranjuez, 28 de mayo de 1740.

57. AGS, SM, leg. 397-2, fol. 373, Ensenada a Arizcun, Aranjuez, 5 de junio de 1740. 
mano de los escudos que se acababan de librar a Arizcun, quien a estas alturas ya tenía experiencia acumulada también como financiero de la Armada.

Cuando el apoderado de Arizcun presentó a la tesorería de Marina las justificaciones de entrega del millón de raciones firmadas por el contador y el intendente de Marina de Ferrol, comprobó que los 300.000 escudos librados por Verdes Montenegro seguían consignados en la Depositaría de Indias a favor de la Real Hacienda sin ni siquiera haberse completado su pago (solo se habían librado 143.846 escudos), lo que a efectos contables significaba que las raciones entregadas a cuenta de esa cantidad no se contabilizaban por la Tesorería de Marina. Para no verse perjudicado en la liquidación final, Arizcun se vio obligado a solicitar al Almirantazgo en un nuevo memorial que la cuenta y razón del total del millón de raciones extraordinarias se sumara a la cuenta general del asiento, que se llevaba en la Tesorería principal de Marina de Cádiz, y que se formara un cargo a su favor de las cantidades libradas a su cuenta por la Depositaría de Indias ${ }^{58}$.

Aparte de las movilizaciones de varios regimientos hacia Galicia y Cataluña, difíciles de ocultar, el Almirantazgo inglés estaba abrumado por los rumores de todo tipo que le llegaban de sus espías. Lo que más les preocupaba era un posible ataque a Mahón o un desembarco en Inglaterra apoyando a los jacobitas, posibilidades que asociaban con los importantes desplazamientos de tropas mencionados ${ }^{59}$. El total desconocimiento de la estrategia que planeaba el gabinete español y de las verdaderas intenciones de Francia sobre su entrada en la guerra aumentaba su intranquilidad. A finales de abril de 1740 al Almirantazgo inglés llegó la noticia, a través de mercantes holandeses que regresaban por el Atlántico a su patria desde Cádiz, de que una escuadra española de más de seis navíos había zarpado de Cádiz a principios de abril con rumbo desconocido. En realidad se trataba de la escuadra del teniente general Manuel López Pintado en su derrota hacia Ferrol para incorporar los navíos a la gran escuadra de Torres. La respuesta del gabinete y del Almirantazgo inglés fue concretar la decisión de enviar más de veinte navíos con tropas regulares a las Indias Occidentales para reforzar la escuadra del almirante Vernon, otra escuadra al Pacífico al mando del almirante Anson y una más al mando del almirante Balchen

58. AGS, SM, leg. 600, Dos memoriales de Miguel de Arizcun dirigidos al Almirantazgo (s.f.). Ensenada a Varas, San Ildefonso, 12 de septiembre de 1740.

59. Rivas IBÁÑEZ, I.: Mobilizing Resources for War: the British and Spanish Intelligence Systems during the War of Jenkins'Ear (1739-1744). VDM Verlag, 2009, pp. 236-238 (Cita de la tesis con el mismo título, London University College, 2008). Sobre la planificada expedición a Menorca: DeYÁ BAUZÁ, J. M.: «El apoyo logístico en el intento de toma de Menorca de 1738-1741», en GUIMERÁ, A. y Peralta, V.: El equilibrio de los Imperios: de Utrecht a Trafalgar. FEHM, Madrid, 2005, pp. 504-517. 
para reforzar la del comandante Ogle y bloquear conjuntamente el puerto de Ferrol, acelerando los preparativos del apresto que se habían iniciado en varios arsenales británicos ${ }^{60}$.

La noticia de tamaña movilización llegó a España en junio. Entonces, para evitar el bloqueo, el Almirantazgo tomó la decisión de que la escuadra de Torres se hiciera inmediatamente a la vela hacia Cartagena de Indias. Todos los víveres y pertrechos que aún no se hubieran embarcado se enviarían posteriormente en mercantes fletados, a ser posible, franceses. Del mismo modo, se debía acelerar el armamento de la escuadra de cinco navíos puesta al mando de José Pizarro para que zarpara desde Santander hacia la Mar del Sur. Torres tuvo que salir precipitadamente de Madrid en una diligencia para asumir el mando de su escuadra, supervisar y acelerar su apresto. Tardó una semana en llegar a Ferrol, lo que nos da idea del estado de los caminos ${ }^{61}$.

Una vez en Ferrol se reunió con el apoderado de Arizcun para hacer un recuento de los víveres, constatando que ya se habían embarcado en los dieciséis barcos de su escuadra (entre los doce navíos de la Armada y los barcos de transporte) las raciones correspondientes para cuatro meses. Sin embargo, de los géneros que estaban depositados en los edificios cercanos al arsenal, faltaban para completar los diez meses de raciones extraordinarias que se había previsto llevara consigo a Indias, 268 quintales y 62 libras de queso y 197 quintales 96 libras y media de tocino. En cambio, había excedentes de vino (12.584 arrobas), carne (1.637 quintales), bacalao (1.015 quintales), menestra (17 quintales), aceite (90 arrobas), vinagre (92 arrobas), trigo (4.100 fanegas) y harina (500 quintales) ${ }^{62}$. Ensenada le tranquilizó, autorizándole a «echar mano de cuantos víveres hubiera en Galicia» para que no se retrasara la partida de la escuadra y, como «nunca serán suficientes para asegurar la subsistencia durante 10 meses de las tripulaciones y guarniciones desde el día que se hagan a la vela», le aseguró que ya había tomado providencias para irle enviando todos los víveres que quedaran en tierra, así como los que fueran necesarios para el sustento de los hombres de la escuadra durante el tiempo que permanecieran en Indias, en mercantes fletados, desde las semanas siguientes a su partida. En la misma forma, Varas iría despachando desde Cádiz la artillería y los pertrechos para los navíos que se hallaban en Indias. Para que

60. Harding, R.: The Emergence..., pp. 65-78.

61. Baudot Monroy, M.: La defensa del Imperio. Julián de Arriaga en la Armada (1700-1754). Cátedra de Historia Naval de la Universidad de Murcia, Ministerio de Defensa, Madrid, 2013, pp. 182-184. AGS, SM, leg. 396, doc. 396, San Ildefonso, 21 de julio de 1740. Ibídem, leg. 397-2, doc. 985 .

62. AGS, SM, leg. 600, Rodrigo Torres a Ensenada, Ferrol, 9 de julio de 1740. «Estado de los víveres que se hallan en los almacenes de este departamento y los que hay a bordo de los 16 navíos hoy 9 de julio». 
Torres pudiera «echar mano» de los víveres que había en Galicia, que eran los que estaban destinados a los regimientos desplazados para la defensa de la costa, Ensenada solicitó a Quintana que el ministro de Guerra de aquellos momentos, el marqués de Ustáriz, diera la orden correspondiente al capitán general de Galicia, el conde de Itre. Apenas una semana después, el marqués de Ustáriz confirmaba que los 2.060 soldados que iban a embarcar en los buques de Torres, lo harían llevando consigo sus respectivas raciones para cuatro meses, así como harinas y otros géneros de repuesto ${ }^{63}$.

Con la misma diligencia se pidió a Varas que fletara con urgencia un mercante francés de los que estuvieran en la bahía gaditana para enviar a Cartagena de Indias los víveres de la escuadra que no habían llegado a tiempo a Ferrol para ser embarcados. Y ciertamente Varas no pudo ser más rápido, pues consiguió que el Alejandro se hiciera a la vela cargado de harinas y pertrechos hacia Cartagena de Indias el 21 de julio, diez días antes que la escuadra de Torres ${ }^{64}$. Consciente de las prisas por hacerse a la vela y de la necesidad de llevar los navíos zafos para poder llamar a zafarrancho de combate en el momento más inesperado, Torres decidió no desembarcar el lastre de los barcos para sustituirlo por muchos de los pertrechos (cables, anclas, calabrotes guindalezas, etc.) que se había previsto llevaran consigo, dejándolos en Ferrol para que se le remitieran posteriormente ${ }^{65}$.

Por fin, el 31 de julio pudo hacerse a la vela con toda su escuadra. A los dos días de navegación se encontraron con una fragata holandesa que se dirigía a Cádiz, manteniéndola navegando en su conserva varios días para impedir que avisase de la partida de la escuadra, como así ocurrió, cuando la fragata, finalmente, entró en Cádiz y propagó la noticia. Varas, que estaba en el secreto de la expedición, pudo neutralizar durante un tiempo la información, esparciendo noticias contradictorias que contribuyeron a mantener la incertidumbre durante semanas ${ }^{66}$.

A lo largo del mes de agosto Arizcun consiguió reunir en Ferrol parte de los géneros que había que ir enviando a Torres. Para almacenarlos debidamente volvió a solicitar a Ensenada que pidiera al intendente de Marina que cediera a su apoderado un almacén. A pesar de la orden recibida, Freyre no condescendió a la solicitud porque de los almacenes disponibles ya había tenido que ceder uno como hospital donde alojar a los soldados enfermos y en el resto estaban todos los pertrechos, armamento y pólvora que había dejado Torres y que había que ir

63. Ibídem, Ensenada a Quintana, Buen Retiro, 12 de julio de 1740. Quintana a Ensenada, Buen Retiro, 13 de julio de 1740. AGS, SM, leg. 396-1, doc. 243, marqués de Ustáriz a José de la Quintana, Buen Retiro, 14 de julio de 1740.

64. AGS, SM, leg. 396-1, doc. 429. Quintana a Ensenada, Buen Retiro, 10 de agosto de 1740.

65. AGS, SM, leg. 600, Torres a Ensenada, a bordo del navío San Felipe, al ancla en el puerto de Ferrol, 20 de julio de 1740.

66. Baudot Monroy, M.: La defensa..., pp. 186-188. 
enviándole, así como los repuestos para los buques del departamento incluso bajo un tinglado aún tenía amontonados varios barriles de harina ${ }^{67}$.

No cabe duda de que el armamento de la escuadra de Torres había supuesto una prueba de fuego para las posibilidades logísticas del departamento marítimo gallego. Si a este hecho le sumamos las prisas del último mes, no es de extrañar que se detectaran muchos fallos en la habilitación de los navíos, sobre todo en los que habían sido habilitados en La Graña, como posteriormente evidenció Torres desde Cartagena de Indias. En efecto, bastante indignado por las faltas que había detectado en el apresto de casi todos los navíos, escribió a Ensenada denunciando las carencias detectadas con la intención de corregirlas «para lo venidero». También encargó una investigación al ministro de la escuadra que señalara todos los errores, pidiéndole que averiguara por qué al menos en tres de los navíos, el San Felipe, el Real Familia y el Santiago, habían faltado raciones durante la navegación, negligencia en la que según Torres: «no ha podido dejar de haber habido omisión grande o malicia de parte de los maestres y proveedor». Torres recomendaba a Ensenada que se revisaran las certificaciones de consumo y que se «reconviniera al asentista» pero no solo por la falta de raciones, sino también por la mala calidad de la pipería y porque se habían encontrado muchos toneles y toneletes podridos ${ }^{68}$.

Aunque estas denuncias llegaron más tarde a oídos de Arizcun, en el mes de agosto la suma de los problemas de este avituallamiento extraordinario y, sobre todo, el enorme descubierto le llevaron a manifestar a Ensenada el deseo de no prorrogar el asiento de provisión de Armada que caducaba el primero de octubre de ese año. Las causas que esgrimió fueron que no podía seguir soportando el descubierto de más de 16 millones de reales y que hasta ese momento continuaba sin recibir reembolso alguno. Sin duda, una razón más que justificada, pero es evidente que desde la posición de fuerza que le daba ser acreedor del Estado intentaba mejorar las condiciones del asiento, como veremos.

La primera medida de Ensenada fue enviar una circular a los intendentes de los tres departamentos avisándoles y pidiéndoles que indagaran si había alguien dispuesto a entrar en el negocio. En caso afirmativo la persona dispuesta a pujar por el asiento debería presentarse en la corte para acordar personalmente las condiciones en la Secretaría de Marina. Como estas diligencias se iban a dilatar en el caso poco probable, por la guerra, de que apareciera algún interesado, Ensenada decidió presionar a Arizcun: «en el supuesto de que se le ayudará con lo que sea posible para sostenerse, proponga V.M. las circunstancias admisibles

67. AGS, SM, leg. 600, Bernardino Freyre a Ensenada, Graña, 20 de septiembre 1740.

68. AGS, SM, leg. 396-2, doc. 762, Rodrigo Torres a Ensenada, a bordo del Nueva España, en el puerto de Cartagena de Indias, 30 de noviembre de 1740. 
en la presente estrechez del Real Erario con que proveerá la armada otro año». Es decir, Ensenada trataba de evitar el cese del asiento mientras durase la guerra.

A pesar de su descontento, Arizcun también fue consciente de que ni podía acabar mal con la real Hacienda, ni renunciar a lo que había sido un buen negocio en otras circunstancias, por lo que empezó a flexibilizar su postura, teniendo en cuenta lo que en aquellos momentos había de positivo en su relación con la Secretaría de Marina: que podía mantener el precio de la ración de armada así como la consignación mensual de 83.000 escudos a cuenta de las Rentas Provinciales de Galicia y de las Rentas Generales de la lana, que durante el último año se le había ido pagando, por lo que aceptó prorrogar el asiento bajo las mismas condiciones del último «para dar más y más pruebas de que no tiene S.M. vasallo más pronto a sacrificarse en su real servicio». La prórroga comprendería un año, desde el primero de octubre de 1740 hasta el 30 de septiembre de 1741, y como garantía de cobro de la cantidades que le correspondían Arizcun pidió a Ensenada que la Tesorería General le entregara las cartas de pago correspondientes a las mesadas de las Rentas Provinciales de Galicia y de la Renta General de la lana para todo el año, así como el pago mensual en dinero por la Tesorería General de la diferencia entre el importe de todas esas rentas y los 83.000 escudos que le estaban consignados $^{69}$. En definitiva, Arizcun quería efectivo para dejar de financiar el aprovisionamiento.

Como era preceptivo, el expediente fue enviado a la Secretaría de Hacienda para que la Junta de Hacienda diera su conformidad. Sin embargo, sus miembros decidieron prorrogar el asiento solo por tres meses más, es decir, hasta finales de diciembre de ese año bajo las mimas condiciones ya citadas, a las que ahora añadían que el asentista debía hacerse cargo de unos bastimentos que por cuenta de la Real Hacienda estaban depositados en Barcelona y en La Coruña, siempre que estuvieran en buen estado para ser consumidos por las tripulaciones. En la resolución el secretario de la Junta de Hacienda informaba de que el transporte de los géneros, así como el seguro correspondiente, correrían por cuenta de la Real Hacienda. Los que estaban en Barcelona se transportarían al puerto de Cartagena y los que estaban en La Coruña al de Ferrol. Una vez que los géneros hubieran llegado a sus respectivos destinos, se entregarían a los apoderados del asentista. Por estos bastimentos Arizcun solo tendría que asumir el coste y las costas que había abonado la Real Hacienda ${ }^{70}$.

69. Ibídem, «Circular a los tres intendentes de Marina» (s. f.). Ensenada a Arizcun, San Ildefonso, 27 de agosto de 1740. Arizcun a Ensenanda, Madrid, 31 de agosto de 1740.

70. Ibídem, Resolución de la Junta de Hacienda comunicada por su secretario a don Cenón de Somodevilla, a don Miguel de Arizcun y a don Fernando Verdes Montenegro, Buen Retiro, 1 de octubre de 1740. 
Arizcun se avino al cambio propuesto por la Junta de Hacienda ${ }^{71}$, no así Ensenada, quien en nombre del Infante-Almirante recurrió la resolución ante el secretario de Estado, marqués de Villarias, alegando que el asentista ya se había comprometido a prorrogar por un año más el asiento bajo las mismas condiciones pactadas en 1735, lo que era más conveniente para la Armada, teniendo en cuenta la situación de guerra y que no hubieran llegado ofertas de otros interesados en el asiento. Villarias así lo entendió y en nombre del rey autorizó al Almirantazgo a rematar el acuerdo para el nuevo asiento con Arizcun, obviando la fiscalización de la Junta de Hacienda. Ensenada retomó la negociación asegurando al asentista como garantía de cobro, que los importes de las Rentas Provinciales de Galicia y de las Rentas Generales de la lana estarían reglados y dotados por la Tesorería General mediante los fondos que se habían aplicado al Almirantazgo provenientes del crédito del Consulado gaditano para el mantenimiento de la Armada durante todo 1741 y que, por lo tanto, también la prórroga se hacía extensiva a todo el siguiente año. Arizcun aceptó hacerse cargo de la provisión de víveres desde octubre de 1739 hasta diciembre de 1741, pero aprovechó la ocasión para pedir algo más: que en el momento de realizarse los pagos, se le diese prioridad frente a otros acreedores y que de los fondos para gasto de Marina adjudicados al Almirantazgo se le entregasen a principios de cada mes los 83.000 escudos consignados a cuenta de todas las rentas en dinero efectivo ${ }^{72}$.

Ensenada, al ver el progreso de la negociación y que Arizcun se allanaba a la prórroga para todo el siguiente año, que era lo que más le importaba para poder seguir bastimentando la escuadra de Torres, dio un paso más allá para asegurarse que no le iban a faltar fondos para el funcionamiento de la Armada. Avisó al asentista de que, garantizado el cobro de las consignaciones mensuales en efectivo y el de las rentas con las cartas de pago emitidas por la Tesorería General, el Infante-Almirante había decidido reservarse los importes correspondientes a dichas rentas en forma de crédito a cuenta de la provisión de Armada para el gasto de la Marina, comprometiéndose a pagarle la cantidad resultante al descontar la diferencia de las consignaciones mensuales al cumplirse el año. Casi a vuelta de correo Arizcun comunicó a Ensenada que el valor de todas las rentas que le correspondían ese año ascendía a 8.540.486 reales de vellón, pidiéndole que dispusiera que esa cantidad se anotara en su haber ${ }^{73}$.

71. Ibídem, Arizcun a Ensenada, Sal Ildefonso, 10 de octubre de 1740.

72. Ibídem, Arizcun a Ensenada, San Lorenzo el Real, 17 de noviembre de 1740. «Orden para que por la Tesorería General se satisfaga a Arizcun mensualmente 83.000 escudos de vellón por su provisión de víveres de Marina de que se encarga hasta fin de diciembre de 1741, comprendido en esta cantidad el importe mensual de las dos rentas que se le consignan y son las Provinciales de Galicia y General de la lana», s. f.

73. Ibídem, Ensenada a Arizcun, San Lorenzo el Real, 3 de diciembre de 1740. Arizcun a Ensenada, Madrid, 19 de diciembre de 1740. Ensenada a Arizcun, 20 de diciembre de 1740. 
Como había conseguido garantizar el cobro de las rentas, Arizcun buscó la posibilidad de hacer lo mismo con el cobro de la consignación mensual acordada, pidiendo que se le asignasen las Rentas Provinciales del reino de León «o las que sean del agrado de S.A., de forma que por este medio perciba efectivamente en cada mes la cantidad convenida». Está claro que a estas alturas Arizcun quería algo más que promesas ${ }^{74}$. Debido a algunos cambios que estaban teniendo lugar en la corte durante el final de 1740, pasaría algún tiempo hasta que Ensenada también le confirmase esta nueva renta en una carta dirigida ya al marqués de Iturbieta ${ }^{75}$.

En efecto, por estas mismas fechas tienen lugar dos acontecimientos que, aunque no guardan ninguna relación entre sí, nos interesa destacar: la concesión del título de marqués de Itubierta a Miguel de Arizcun y el nombramiento de José del Campillo como secretario de Hacienda, primero, y a las pocas semanas también de Guerra, Marina e Indias ${ }^{76}$. La concesión del título de Castilla al asentista tiene lugar en enero de $1741^{77}$. Suponía el mayor reconocimiento social al que podía aspirar un hombre de negocios, a la vez que un trampolín para consolidar un importante patrimonio y, en este caso, un reconocimiento y una última concesión más de la corona a Arizcun para sellar la prórroga del asiento de víveres que tanto necesitaba.

El nombramiento de Campillo tras el cese de Verdes Montenegro en un principio no trajo consigo cambios significativos en relación con el asiento, que ya estaba pactado y bien atado por ambas partes y Arizcun había seguido provisionando con víveres a la Armada. Sin embargo, en mayo de 1741, Campillo, a modo de visto bueno suyo a la prórroga del asiento y para que constara, escribió al tesorero general, José Gómez Terán, informándole de las condiciones acordadas entre Ensenada y el asentista, entre las que, sorprendentemente, ya no figuraban las Rentas del reino de León. También le ordenaba que abonara a Arizcun mensualmente las cantidades que le correspondían hasta el final del asiento, en diciembre de 1741. Es muy probable que el hecho de no confirmar el ministro de Hacienda la concesión de una nueva renta respondiera a su intención de limitar los recursos en manos de los asentistas. Como de hecho hizo, cuando tras la muerte de Arizcun negoció una nueva prórroga con su primo, Ambrosio de Garro, quien se había hecho cargo de la Casa de Arizcun. En el nuevo contrato Campillo recuperó para la corona el privilegio de la exención fiscal para todos los géneros del que se había beneficiado la Casa cuando Miguel de Arizcun estuvo al frente. También rebajó la duración del contrato de cinco a tres años. Esta retirada de privilegios

74. Ibídem, Arizcun a Ensenada, Madrid, 22 de diciembre de 1740.

75. Ibídem, Ensenada al marqués de Iturbieta, 20 de febrero de 1741.

76. Escudero, J. A.: Los orígenes del Consejo..., p. 111. Perona Tomás, D.: Los orígenes..., pp. 131-132, 394.

77. Aquerreta González, S.: «La Casa de Arizcun...», pp. 659-677. 
responde a los primeros pasos de Campillo en su intención de reorganizar las rentas de la Monarquía imponiendo progresivamente su recuperación y la consiguiente administración directa de los servicios cedidos. Sin embargo, debido a la guerra y a su repentino fallecimiento al poco tiempo de acceder al cargo, no pudo desarrollar su proyecto ${ }^{78}$.

Ante la fatalidad que hizo coincidir el inicio de la guerra con la quiebra del Estado, provocando una complicada situación económica, agravada por la restrictiva política financiera de los ministros de finanzas, la corona tuvo que recurrir a un préstamo del Consulado gaditano para poder movilizar los recursos necesarios para armar las escuadras. Hemos visto cómo Ensenada en una situación extrema se las ingenió para conseguir el dinero que necesitaba de donde supo que lo había: en manos de Miguel de Arizcun. Los asentistas fueron los mayores perjudicados por la suspensión de pagos, pero Arizcun, a pesar del descubierto acumulado y de la incertidumbre para solventarlo, siguió cumpliendo con la obligación contraída y financió la provisión de víveres a la Marina. La guerra dificultó el negocio del aprovisionamiento: la compra, el transporte y la distribución de los géneros a los puertos donde debían embarcarse y la corona entendió que tenía que ser flexible, eliminando los obstáculos que hubieran impedido bastimentar las escuadras. Lo hizo en forma de excepciones legales y concesión de privilegios al asentista, que en ocasiones supusieron cesión de derechos.

Poco antes de que caducara el asiento, Arizcun anunció su intención de renunciar por la deuda acumulada. El Almirantazgo, presionado por la necesidad de garantizar el funcionamiento de las escuadras que estaban actuando, luchó para que la Administración facilitara una prórroga. Durante la negociación también Arizcun entendió que, aunque por su situación de acreedor hubiera estado en condición de mejorar considerablemente las disposiciones del contrato, tenía que mostrarse flexible y se contentó con recibir pagos en efectivo. Frente a la facilidad con que la Royal Navy y el Victualling Board pudieron conseguir la financiación para armar y avituallar sus escuadras, la Armada tuvo que hacer un gran esfuerzo para vencer las rigideces financieras impuestas por la Secretaría de Hacienda y las que entrañaba la Administración estatal. Está claro que sin la colaboración entre el Almirantazgo y Arizcun para vencer las contradicciones que generaba la mutua dependencia entre la corona y los asentistas, ni Arizcun hubiera podido cumplir el contrato, ni la Armada hubiera podido bastimentar sus escuadras.

78. Torres SÁnchez, R.: «Servir al rey...», pp. 164-165. Del mismo autor: «Los navarros...», pp. 246-249. 


\section{BibliografíA}

Aquerreta GonzÁlez, S.: «Reforma fiscal y continuidad en el sistema de arrendamientos: la renta de lanas en el reinado de Felipe V» en González Enciso, A. (ed.): El negocio de la lana en España, (1650-1830), Eunsa, Pamplona, 2001, pp. 109-133.

Aquerreta González, S.: «La Casa de Arizcun 1725-1742: las estrategias financieras de un hombre de negocios en el Madrid de la Ilustración» en Ferrer Benimeli (dir.); Sarasa, E., Serrano, E. (coords.): Congreso Internacional El conde de Aranda y su tiempo, Diputación de Zaragoza, Zaragoza, 2000, vol. 1, pp. 659-678.

Baudot Monroy, M.: La defensa del Imperio. Julián de Arriaga en la Armada (17001754), Cátedra de Historia Naval de la Universidad de Murcia, Ministerio de Defensa, Madrid, 2013.

Baugh, D.: British Naval Administration in the Age of Walpole, Princeton University Press, Princeton, 1965.

Brunsman, D.: «The Knowles Atlantic Impressments Riots of the 1740s», Early American Studies, Fall (2007), pp. 324-366.

http://dx.doi.org/10.1353/eam.2007.0010

Ceballos-Escalera y Gila, A. de: El Almirantazgo general de España e Indias en la Edad Moderna, Real Academia de la Mar, Madrid, 2012.

Cruz Mundet, J. R.: «Juan Bautista de Iturralde y Gamio, un asentista navarro en la corte de Felipe V», Príncipe de Viana, 255, (2012), pp. 205-259.

Deyá Bauzá, J. M.: «El apoyo logístico en el intento de toma de Menorca de 1738-1741», en Guimerá, A. y Peralta, V.: El equilibrio de los Imperios: de Utrecht a Trafalgar, FEHM, Madrid, 2005, pp. 504-517.

Fernández Albaladejo, P.: «El decreto de suspensión de pagos de 1739: análisis e implicaciones», Moneda y Crédito, 142, (1977), pp. 51-85.

Fernández Albaladejo, P.: Monarquía, Imperio y pueblos en la España Moderna, Universidad de Alicante, AEHM, Alicante, 1997.

Fernández Díaz, R. y Martínez Shaw, C.: «Las revistas de inspección de la Matrícula de Mar en el siglo XviII» en Martínez SHaw, C.: El Derecho y el mar en la España Moderna, Granada, 1995.

Gómez URdáñez, J. L.: El proyecto reformista de Ensenada, Milenio, Lérida, 1996.

Gual Truyol, S.: La expedición de Mabón, 1738-1741, Museo Histórico Militar de Menorca, 1993, pp. 18-20.

HARDING, R.: The Emergence of Britain's global naval Supremacy. The War of 1739-1748, The Boydell Press, Woodbridge, 2010.

Hilton, S. L.: «El conflicto anglo-español en Florida: utopía y realismo en la política española, 1732-1739», Quinto Centenario. Revista Complutense de Historia de América, 5, (1983), pp. 97-130,

IBÁÑEZ Molina, J.: Rentas provinciales, administración real y recaudadores en el reinado de Felipe V, (1700-1739), Universidad de Granada, Granada, 1986.

Jurado SÁnchez, J.: «Proyectos para reducir el gasto de la Hacienda española en el siglo XviII», Cuadernos de Estudios Empresariales, 14, (2004), pp. 105-129. 
Ordenanzas generales de la Armada naval. Sobre la gobernación militar y marinera de la Armada en general y uso de las fuerzas en la mar, dos volúmenes, Madrid, en la imprenta de la viuda de D. Joaquín Ibarra, 1793.

Ozanam, D.: «La política exterior de España en tiempo de Felipe V y de Fernando VI», en Historia de España de Ramón Menéndez Pidal, t. XXIX, Madrid, 1985, pp. 443-640.

Pérez Fernández-Turégano, C.: «El Almirantazgo del Infante D. Felipe (1737-1748). Conflictos competenciales con la Secretaría de Estado y del Despacho de Marina», Anuario de Historia del Derecho español, 74, (2004), pp. 409-476.

Pérez Fernández-Turégano, C.: Patiño y las reformas de las Administración en el reinado de Felipe V, Ministerio de Defensa, Madrid, 2006.

Perona Tomás, D.: Los orígenes del Ministerio de Marina, Ministerio de Defensa, Madrid, 1999.

RIVAs Ibáñez, I.: Mobilizing resources for war: the British and Spanish intelligence systems during the war of Jenkins'Ear (1739-1744), VDM Verlag, 2009.

Rodger, N. A. M.: The Wooden World. An Anatomy of the Georgian Navy, Norton E Company, Nueva York, 1996.

Tapias Herrero, E.: «El Teniente general López-Pintado, cargador a Indias, jefe de escuadra y marqués de Torreblanca del Aljarafe», Revista General de Marina, (259), 2010, pp. 409-418.

Torres SÁnchez, R.: «Servir al rey, más una comisión. El fortalecimiento de los asentistas en la corona española durante la segunda mitad del siglo XVIII» en FERNÁndez Albaladejo, P.: Monarquí, Imperio y pueblos en la España Moderna, Universidad de Alicante, 1997, pp. 149-166.

Torres SÁnchez, R.: «Los navarros en la provisión de víveres a la Armada española en el siglo XVIII» en Torres Sánchez, (ed.): Volver a la hora navarra. La contribución navarra a la construcción de la Monarquía española en el siglo XVIII, Eunsa, Pamplona, 2010, pp. 213-262.

Torres SÁnchez, R.: «Cuando las reglas del juego cambian. Mercados y privilegios en el abastecimiento del Ejército español en el siglo XviII», en Revista de Historia Moderna. Anales de la Universidad de Alicante, Varia, 20 (2002), pp. 5-66.

VÁzquez Lijó, J. M.: La matrícula de mar en la España del siglo XVIII, Ministerio de Defensa, Madrid, 2007.

Wilson, K.: The Sense of the People: Politics, Culture and Imperialism in England, 17151785, Cambridge University Press, Cambridge, 1998.

Woodfine, P.: Britannia's Glories. The Walpole Ministry and the 1739 War with Spain, Boydell \& Brewer Ltd., Nueva York, 1998. 